\title{
THE POLYCHNITOS IGNIMBRITE OF LESVOS ISLAND
}

\section{S. LAMERA ${ }^{1}$, K.ST. SEYMOUR ${ }^{1}$, C. VAMVOUKAKIS ${ }^{1}$, M. KOULI ${ }^{1}$, E. PARASKEVAS ${ }^{1}$, PE-PIPER ${ }^{2}$}

\section{ABSTRACT}

Miocene volcanism on Lesvos was particularly explosive giving rise to two extensive pyroclastic formations, the Sigri pyroclastics to the west and the Polychnitos ignimbrite to the east of the island. The Polychnitos ignimbrite at $17.2 \pm 0.5 \mathrm{Ma}$ (Borsi et al.1972) is part of the shoshonitic succession on Lesbos which ranges in composition from basalt to rhyolite and is both underlain and overlain by calcalkaline volcanic rocks (Pe-Piper and Piper 1993) resting on a late Paleozoic metamorphic basement which has acted as an impediment to the free flow of the ignimbrite. The Polychnitos ignimbrite consists of eight lithological units, six of which are presumed to be facies of the same ignimbrite sheet ("PK", "PU", "MGF I, II, III", "Z"). Ignimbrite deposition at elevated temperatures is advocated by its columnar jointing, eutaxitic texture, gas escape structures and glassy zones of intense welding. The typical mineral assemblage of all Polychnitos ignimbrite units consists of plagioclase, Kfeldspar and biotite. It displays phenocryst microtextures indicative of magma mixing. Magma mixing is corroborated of glasses of two discrete compositions. Lithic clast measurements indicate a northeasterly trending fissure vent passing from the northeastern corner of the Kalloni Gulf.

KEY WORDS: Polychnitos ignimbrite, ignimbrite petrology, source, magma mixing, shoshonitic Miocene Cenozoic Volcanism, Lesbos.

\section{INTRODUCTION}

The island of Lesvos lies off the coast of Asia Minor in northeastern Aegean (Fig.1) and mostly consists of a Tertiary volcanic succession on a Late Paleozoic metamorphic basement. The volcanic succession comprises of shoshonites ranging from basalt to rhyolite, both underlain and overlain by calcalkaline volcanic rocks. The shoshonitic volcanic rocks range in compositions from andesite to rhyolite in the form of flows, domes and pyroclastics (Pe-Piper and Piper, 1993). Miocene volcanism in northern Hellas and the Aegean Archipelago was the result of the subduction of Africa under Eurasia but with a different geometry of plates than the one which has resulted in the present Quaternary Volcanic Arc which lies more to the south. The petrology and geochemistry of the volcanic succession in Lesvos were first described by Von Hauer (1873) and later by Georgalas (1949), Prager (1966), Borsi et al. (1972), Hecht (1972-5). Pe-Piper (1979) subdivided the Miocene-Pliocene volcanic rock stratigraphy of Lesvos on the basis of field relationships, paleomagnetic polarity and radiometric dating using Hecht's map as a base.

\section{IGNIMBRITE STRATIGRAPHY}

A polymictic breccia underlies the Polychnitos ignimbrite sheet. Lapilli tuff, tuff breccia and agglomerates were discontinuously mapped at the base of the ignimbrite by Hecht (1972-5). We have additionally to Hecht's occurences mapped the breccia in three positions, one of which was on Barbalia island (Fig.1). This unit presents a different lithological character depending on the rocks underlying the Polychnitos ignimbrite, therefore we feel it might represent a basal (foot) breccia to it. For example, to the north and northeast, where the ignimbrite is in contact with the lavas and domes of the "Lower Lava Unit" of Pe-Piper (1979), the breccia is observed in a small quarry near Mantamados to underlie the base of the ignimbrite and be stubbed with clasts of a felsic lava with lithologies similar to the ones of Kapi rhyolite (this work and Pe-Piper, 1979).

The Polychnitos ignimbrite consists probably of eight (8) cooling units (including MGF I, II, III, see below) all observed superimposed only at one location at the end of a small private road at the Skala of Mistegna (Fig.1). The relative stratigraphic position and the lithological characteristics of six cooling units and the discon-

1.Postgraduate student, University of Patras, Laboratory of Ore Deposits and Volcanology, 26500 Patras, Hellas 


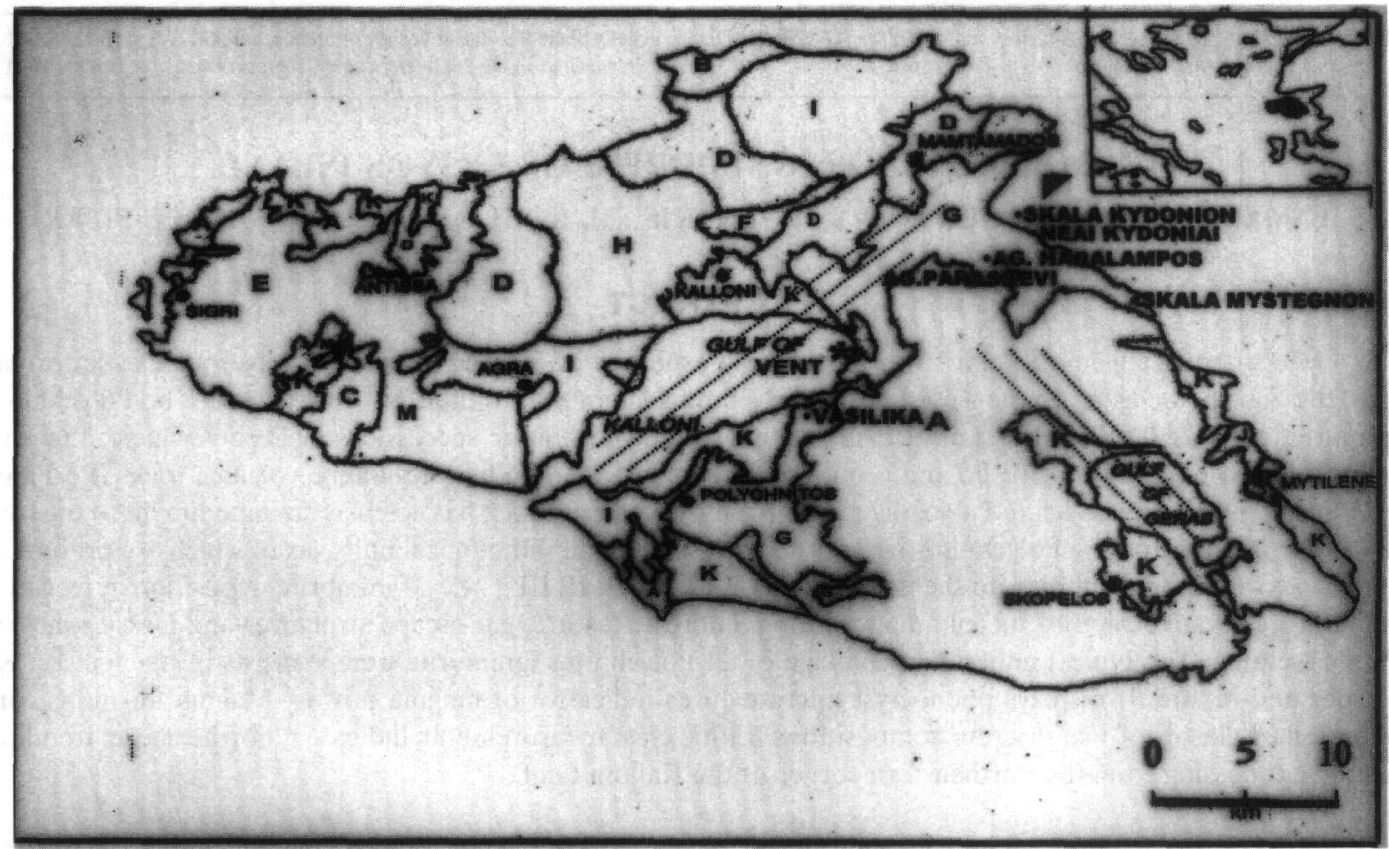

Figure 1: Geological map of Lesbos island modified from Pe-Piper and Piper, 1992. Asterisk: proposed vent of Polychnitos ignimbrite. Dashed lines: Grabens of the Gulfs of Kalloni and Gera. The black triangle is the Barbalia island. Stratigraphy from bottom to top: A:basement, B:undivided lower lavas, C: Eressos formation, D:Skoutaros formation, E:Sigri pyroclastic formation, F:Kapi rhyolite formation, G:Polychnitos and Skopelos ignimbrites, H:Skalohorion formation, I:Sykaminea formation, J:Mytilene formation, M: Mesotopos dykes, K: post-Miocene sediment.

\begin{tabular}{|c|c|}
\hline "Z" & QUARRY UNIT \\
\hline "MGF" & MEGAFIAMMA UNIT \\
\hline "PU" & PURPLE UNIT \\
\hline "PK" & PINK UNIT \\
\hline "GR" & GREY UNIT \\
\hline "WH" & WHITE UNIT \\
\hline "BRCC" & BASAL BRECCIA \\
\hline
\end{tabular}

Figure 2:

Idealized stratigraphic column of Polychnitos ignimbrite 
tinuous basal breccia have been established in this work and are depicted in the idealized section of Fig.2. At least two or more units are absent in each outcrop. The type localities where exposure is more complete is at the village and Skala of New Kidoniai (Fig.1) and on the roadcut at the northeast tip of the Gulf of Kalloni (Fig.1). The lithological descriptions of the units are given here from the top towards the bottom.

\section{"Z" "Quarry Unit"7}

This unit is very poor in lithic (2-6\%) and pumice component $(0-10 \%)$. When present the fiammes are small, whitish, weathered, lightly welded, and are concentrated near the base of the unit together with the sparse lithic components. It is a pink unit displaying prominent columnar jointing and good welding, signs of having been deposited at elevated temperatures. Since the " $Z$ " Quarry Ignimbrite is well welded and quite indurated, it is used for masonry, as building-and tomb-stone. The phenocryst component is 6-30\%. The main mineral assemblage includes plagioclase, K-feldspar and biotite.

\section{"MGF" "Megafiamme Unit" 6}

This consists of three cooling subunits (I,II,III) with visible contacts at the type location Skala of N. Kydoniai. It is characterized by a pinkish, earth-brown colour, progressive upwards depletion in lithic components (10$20 \%$ and up to $30 \%$ in some sections) and increase in the size of fiammes the content of which varies between 10$30 \%$. It is a well welded (vitric zones near Agios Charalambos, Fig.1) to moderately welded unit with gently curving columnar jointing, lithified, characterized by gas holes and "frothy" flow tops and large, black glassy fiammes with rugged, flame-like terminations in good eutaxitic arrangement. Within each subunit the size of the fiamme increases upwards. The pink-brown colour of the matrix is due to devitrification. The unit is crystal-rich $(10-40 \%)$ with crystals of plagioclase, K-feldspar, biotite and some quartz diminishing from I to III. The "Megafiamme Unit" is of extensive occurrence.

\section{"PU" "Purple Unit" 5}

This is an extensively outcropping unit, present in a large number of roadcuts on the paved roads connecting Mytilene-Mamtamados, Mytilene-Kalloni, Vasilika-Polychnitos and the unpaved road connecting Agia ParaskeviAgios Charalambos. The unit is characterized by a purplish-tint colour, good to excellent welding with black, glassy fiammes (up to 20\%) and a purplish devitrified matrix rich in lithic (10-15\% and up to $25 \%$ in some sections) and crystal components (10-35\%). Well rounded, whitish lithics are ubiquitous and characteristic for this unit, and aid to its identification.

\section{The units of White, Grey and Pink Ignimbrite}

At the northeastern side of the Gulf of Kalloni, the following stratigraphic units have been identified:

a) White ignimbrite: the unit consists of pumiceous matrix which contains grey, black and red glassy lithic fragments (15\%), the size of which ranges from 3 to $5 \mathrm{~mm}$, and thin, non-welded fiammes (15\%). A small subunit has been recognised at the top of this unit, with very characteristic layering (marked as parallel lines at the top of "WH" unit in Fig.2) of large lithic fragments (up to 60\%) which are concentrated near the contact with the underlain white unit. The lithic fragments in this layered subunit seem to be similar to the ones in the underlain ignimbrite.

b) Grey ignimbrite: the unit consists of very fine grey matrix, with white, non welded fiammes (up to $20 \%$ ), the size of which is $1-2 \mathrm{~cm}$, and purplish lithic fragments (2-3\% and up to $10 \%$ in some sections), up to $2 \mathrm{~cm}$ large. The phenocryst component is $5-17 \%$ and the main mineral assemblage includes K-feldspar, biotite and quartz. The grey ignimbrite is not welded. It has been observed near the monastery of St. Charalambos, at the entrace of the village Vasilika (Fig.1) and on the Barbalia island.

c) Pink ignimbrite: the unit consists of pink, fine-grained pumiceous matrix rich in lithic fragments of grey and brown-red colour, which have been derived from aphyric lavas and have a cherty surface. The phenocryst content is $10-15 \%$. A lot of biotite and quartz crystals are present. The fiammes (5-20\%) are of white colour, small and rugged, with size ranging from $0.5-3 \mathrm{~cm}$.

\section{PETROGRAPHY OF THE POLYCHNITOS IGNIMBRITE}

\section{Crystals \& Crystal Fragments}

The main crystalline assemblage in the cooling units of the Polychnitos ignimbrite consists of plagioclase (2-40\%, average 
between $10-20 \%)$, K-feldspar and biotite (0-10\%, average between 3-4\%). The plagioclase is andesine and anorthoclase.

Other crystals include clinopyroxene and rare quartz, apatite, sphene and inherited olivine. The feldspars and biotite all display signs of deformation and strain such as: undulatory extinction, shattered or partly broken or bend crystals. This is expected from the pyroclastic character of the host rock. Some deformation in a plastic state has been expressed, such as bending of the crystals around (presumably hot) pumice fragments (fiammes).

Disequilibrium growth of the crystalline assemblage is indicated by the complex mineral zoning in the plagioclase and pyroxene crystals. Extremely unstable conditions are indicated for the final stages of crystal growth, by the intensely resorbed rims of biotite and plagioclase and the K-feldspar overgrowths on plagioclase and dark rims on clinopyroxene. Decompression during ascent is indicated by the "sieve" cores of plagioclase and biotite. Degassing, high $\mathrm{fO}_{2}$ and contiguous mixing in the subvolcanic magma chamber are indicated by a plethora of features: ubiquitous opaque oxide dusting which is pervasive, resorbed, skeletal biotite and other phenocrysts, synneusis of phenocrysts and the presence of two glasses in mechanical mixing textures (ribbons), separate shards or chemical mixing (ie. the presence of unmixing ocelli).

\section{Pumice fragments - Fiamme}

We have discerned two end member types (forms) of pumice fragments:(1) Firstly, pumice fragments with irregular nonflattened shape and spherical vesicules; on the other end of the morphological spectrum, with all possible variations existing in between, there is flattened lenticule-like obsidian glass with perlitic and conchoidal fracturing, eutaxitic arrangement, rugged, flame-like edges and with collapsed, or most commonly elongated, vesicules. This second type of pumice has been deposited at elevated temperatures ie. in a plastic state and has collapsed during welding and development of the eutaxitic texture.

The percentage of the pumice fragments ranges between $0-30 \%$ and that of the fiamme between $0-25 \%$. The sperical vesicules are often lined with tridymite (vapour phase crystallization). In one case of pumice fragment, glass of a different refraction index has been observed to form unmixing ocelli.

The most-collapsed pumice fragments have perlitic texture and are commonly in a more advanced state of devitrification, as indicated by the ubiquitous presence of spherulites and of alteration (oxidation) as becomes apparent from abundant opaque oxides. This is mainly due to the fact that they display a larger reactive surface vis- $\hat{v}$-vis their collapsed counterparts.

Sparse crystals are found in the fiamme and pumice fragments in the same mineral assemblage, with the exception of clinopyroxene, as in the one found in the crystic assemblage of the ignimbrite.

\section{Lithic Components}

They can be as high as $45 \%$ (average 10\%), or they can be almost completely absent (eg. "Z" Quarry Unit). They range in size from microscopic to over $4 \mathrm{~cm}$ and near the proposed here ignimbrite fissure vent, over $13 \mathrm{~cm}$. The lithic components, particularly in the PU ignimbrite, are subrounded to subangular. Many lithics are altered. Lithic components of volcanic origin are the most common and those of plutonic origin are the most rare. Plutonic lithic components represent probably autoliths of the subvolcanic magma chamber since they represent possible combinations of the main phenocrystic assemblages of the ignimbrite.

Lithic components of metamorphic origin include weathering-resistant rocks such as quartzite and sandstone. Serpentinite rounded fragments are ubiquitous, especially in the PU ignimbrite, due to the proximity and extensive interpacing of this ophiolite with the Polychnitos ignimbrite.

The volcanic lithic clasts range in composition from basalt-andesite, to dacite, to rhyolite. Fragments very similar lithologically to the Kapi rhyolites are the most common ones in the ignimbrite sharing a border with them (Fig.1).

Microscopically, the lithic components are observed to have acted as rigid anchors, with the glass shards and fiammes being in plastic-state and either drapping (mandling) over or being squeezed between them. Devitrification of glass is not uncommon when in contact with lithic components.

\section{DISCUSSION \& CONCLUSIONS}

The Polychnitos ignimbrite is an important pyroclastic unit, part of the shoshonitic succession of Tertiary volcanism on the island of Lesbos, and occupies the $1 / 6$ of the central eastern part of Lesbos. The Sigri pyroclastics in the west part of the island is another extensive formation. One has to conclude that Tertiary volcanism on Lesbos was particularly explosive in character. The Polychnitos ignimbrite has been K/Ar dated by Borsi et al. (1972) at 17.2 $\pm 0.5 \mathrm{Ma}$ and a correlative ignimbrite from Asia Minor at $17.5 \pm 0.5 \mathrm{Ma}$ (Karacik and Yilmaz, 1995). SPOT image observations (Kouli et al., 2001, in preparation) have identified the possible continuation of the Polychnitos ignimbrite on a small island northeast of the Barbalia island, where it has been located, just off the coast of Asia Minor (Fig.1). 
Six (6) lithological units ("WH", "GR", "PK", "PU", "MGF", "Z") have been identified in the field underlain by a basal polymicticbreccia(Fig.2). This is reportedbyHecht(1972-5)tobe a lapillituff, or tuffbreccia or agglomerate. The MGF(Megafiamme Unit, Unit 6 of Fig.2), consists of three (3) cooling subunits: (MGF I, II, III). In SPOT-PAN imaging the POLYCHNITOS ignimbrite displays 6 discontinuous terraces (Kouli et al., 2001, in preparation) which most probably correspond to the following lithologies of Figure 2:(1) Basal Breccia (2) Purple Ignimbrite (3), (4), (5) MGF I, II, III and (6) the Z-Quarry Unit.

Overall depletion in lithic components from unit GR to Z, maximum welding with glassy inferiors mostly in the PU unit, increase in fiamme size upwards, with a maximum in the MGF cooling unit and the nature of the Z unit which alludes to an origin from the most elutriated parts of the pyroclastic flow, all these argue that PU to Z represent cooling units of the same ignimbrite sheet and the lithological variations we observe express a vertical facies change.

Maximum and average lithic component measurements in the PU unit indicate that the Polychnitos ignimbrite sheet has originated from a fissure vent paralleling the Kalloni graben and particularly in the northeastern comer of the Gulf of Kalloni (Fig.1). Flow directions in the ignimbrite derived from tephra orientations by Pe-Piper (1979) following the techniques developed by Elston \& Smith (1970) and our SPOT-PAN image observations (Kouli et al, 2001, in preparation), all agree with this localization of the ignimbrite vent and also point to the fact that the 108 Ma metamorphic basement has acted as an impediment prohibiting the free flow of the ignimbrite to the southeast and even in the graben of Geras Gulf. Due to the restricted occurrence of the Skopelos ignimbrite (Pe-Piper, 1979) this argument will not be challenged even if this unit is correlative to the Polychnitos ignimbrite.

Complex zoning patterns in the plagioclase and clinopyroxene, hiatus in the crystal growth of plagioclast phenocryst(Pe-Piper, 1979;1980), the presence of two compositions of glass shards and streaks of glass of contrasting compositions in the pumice fragments, all these argue for magma mixing having played an important role in the Lesbos subvolcanic magma chamber.

\section{REFERENCES}

BORSI, S., FERARRA, G., INNOCENTI, F. AND MAZZUOLI, R. (1972), Geochronology and petrology of recent volcanics in the Eastern Aegean Sea (West Anatolia and Lesvos Island), Bulletin of Volcanology, Vol. 36, pp. 473-493.

ELSTON, W. E., SMITH, E. L. (1970), Determination of flow direction of rhyolithic ash flow tuffs from fluidal textures, Bulletin of Geological Society of America, Vol. 81, pp. 3393-3406, Boulder, Colo.

GEORGALAS, G., (1949), Contribution à la connaissance de roches eruptives de la île de Metélin, Bulletin of Volcanology, Vol. 9, pp. 31-63, Napoli.

HAUER, F., V. (1873), Analysenvon Felsarten von Mytilini, Verh. Geol. Reichsanst., Jg. 1873, pp. 218-222, Wien.

HECHT, J. (1972-1975),IGME, Geological map of Greece, 1:50.000. Plomari-Mytilene, Ayia Paraskevi, Mithimna, Polichnitos and Eressos sheets.

KARACIK,Z.AND YILMAZ, Y. (1995), Geology of the ignimbrite eruptionsof Ezine-Ayvacik region, NW Anatolia, Proceedings of the "International Earth Sciences Colloquium on the Aegean region", Vol.2, pp.415427, Izmir-Gulluk, Turkey.

PE-PIPER, G. (1979), Source of Miocene ignimbrites of Lesvos as shown by tephra orientations, Proc. VI., Colloq. Geol. Aegean Region, vol. 3, pp. 939-944, Athens.

PE-PIPER, G. (1980), Geochemistry of Miocene shoshonites, Lesbos, Greece, Contributions to Mineralogy and Petrology, Vol, 72, pp. 387-396, Berlin.

PE-PIPER, G. (1992), Geochemical variation with time in the Cenozoic high-K volcanic rocks of the island of Lesbos, Greece; Significance for shoshonitic petrogenesis, Journal of Volcanology and Geothermal Research, 53, pp. 371-387.

PE-PIPER, G. AND PIPER D.J.W.(1993), Revised stratigraphy of the Miocene volcanic rocks of Lesbos, Greece, N. Jb. Geol. Paläont. Mh, H2, pp. 97-110.

PRAGER, M. (1966), Presentation d'une esquisse geologique des terrains volcaniques de l' île de Lesbos (Grèce), Ann. Geol. Pays Hellen., Vol. 16, pp. 512-527, Athènes.

KOULI et al.(2001), (Title in preparation) 